\title{
Anarchism and Religion: Exploring Definitions
}

\author{
Alexandre Christoyannopoulos \& Matthew S. Adams \\ Loughborough University, UK
}

One of the contested features in the scholarship on both anarchism and religion has been the question of definition. How one defines key terms does, after all, determine what one analyses (and what not), and generally reveals one's assumptions and preferences (implicit or explicit) about what is being discussed. Also, the same term can mean different things in different languages, times and places, even if deliberately employing a pre-existing term does usually signal intended alignment. To make matters more difficult, in some cases, definitional differences are not just merely minor and contextual, but deliberate and fought over, sometimes with a clear intention to exclude particular variants that are felt to precisely not legitimately fit the label. Indeed, both 'anarchism' and 'religion' are candidates for Gallie's definition of 'essentially contested concepts': "concepts the proper use of which inevitably involves endless disputes about their proper uses on the part of

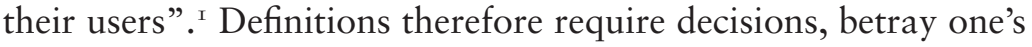
particular sympathies and aversions, and reflect one's context.

For anarchists in particular, as much as 'protean fluidity' is a hallmark of the tradition and often a source of pride, some boundaries can be defended with much passion. ${ }^{2}$ For instance, most anarchists are particularly insistent on excluding

I W. B. Gallie, "Essentially Contested Concepts," in The Importance of Language, ed. M. Black (Ithaca, NY: Cornell University Press, I962), I 23 .

2 George Woodcock, Anarchism: A History of Libertarian Ideas and Movements (London: Penguin, I986), p. 4I4.

How to cite this book chapter:

Christoyannopoulos, A. and Adams, M. S. 2018. Anarchism and Religion: Exploring Definitions. In: Christoyannopoulos, A. and Adams, M. S. (eds.) Essays in Anarchism and Religion: Volume II. Pp. I-I9. Stockholm: Stockholm University Press. DOI: https://doi.org/IO.I6993/bas.a. License: CC-BY. 
'anarcho-capitalism' from 'anarchism'. ${ }^{3}$ Others reject any flavour of religion. ${ }^{4}$ Some claim that only 'class struggle' anarchists should be labelled 'anarchists'. ${ }^{5}$ Some devote much time to reflecting on the place of anarchism in political thought, whereas others insist on the prioritisation of praxis over theory. ${ }^{6}$ Some explain anarchism by focusing on the writings of the 'classical anarchists' of the nineteenth century, others advocate 'blasting' that 'canon' and adopting a more open and critical anarchist historiography. ${ }^{7}$ That anarchism occupies an ambiguous position in the family of political ideologies - seemingly fusing a trenchant demand for

3 The Anarchist FAQ Editorial Collective, "An Anarchist Faq," https:// theanarchistlibrary.org/library/the-anarchist-faq-editorial-collectivean-anarchist-faq\#toc7.

${ }^{4}$ Harold Barclay, "Anarchist Confrontations with Religion," in New Perspectives on Anarchism, ed. Nathan Jun and Shane Wahl (Lanham, MD: Lexington, 20I0); Alexandre Christoyannopoulos, "Christian Anarchism: A Revolutionary Reading of the Bible," ibid.; Alexandre Christoyannopoulos and Lara Apps, "Anarchism and Religion," in Brill's Companion to Anarchism and Philosophy, ed. Nathan Jun (Leiden: Brill, 2018); Sébastien Faure, "Does God Exist? Twelve Proofs of the NonExistence of God," The Anarchist Library, http://theanarchistlibrary. org/library/sebastien-faure-does-god-exist; Johann Most, "The God Pestilence," Anarchy Archives, http://dwardmac.pitzer.edu/Anarchist_ Archives/bright/most/godpest.html; Nicolas Walter, "Anarchism and Religion," The Raven: anarchist quarterly 257, no. I (I994).

5 Nathan Jun, "Rethinking the Anarchist Canon: History, Philosophy, and Interpretation," Anarchist Developments in Cultural Studies I (2013); Robert Graham, "Black Flame: A Commentary," ibid.; Michael Schmidt and Lucien van der Walt, Black Flame: The Revolutionary Class Politics of Anarchism and Syndicalism (Oakland: AK, 2009); Lucien van der Walt, "(Re)Constructing a Global Anarchist and Syndicalist Canon: A Response to Robert Graham and Nathan Jun on Black Flame," Anarchist Developments in Cultural Studies I (2013).

${ }^{6}$ Nathan Jun, "Anarchism and Philosophy: A Critical Introduction," in Brill's Companion to Anarchism and Philosophy, ed. Nathan Jun (Leiden: Brill, 20I8). More generally, unsurprisingly in light of anarchism's radicalism and its emphasis on action, debates and tensions between those who spend much time theorising and those keener to focus on activism crop up sooner or later in nearly any anarchist circle.

7 Matthew S. Adams, "The Possibilities of Anarchist History: Rethinking the Canon and Writing History," Anarchist Developments in Cultural Studies I (20I3); Ruth Kinna and Süreyyya Evren, "Introduction: Blasting the Canon," ibid. 
thoroughgoing equality which is characteristic of socialism with an equally robust defence of liberty which is most commonly seen in radical forms of liberalism - can also add confusion for the uninitiated. Then there is the debate about political violence: for a political tradition that prides itself on its practical efficacy - on its ability to occasion change in the here and now, both in individual mentalities and in offering fresh models of political participation the flawed but common association with seemingly gratuitous destruction is unhelpful. ${ }^{8}$ Being in a position to point, instead, to the constructive acts of anarchists, and to their richly varied philosophies, including by offering a definition that either detaches 'anarchism' from its narrow association with political violence or at least focuses on its ideological content (irrespective of whether it sometimes informs 'violence'), could support an act of recovery.

As for 'religion', some employ the term broadly to include all the spiritualities and practices which can be considered 'religious', whereas others insist on the label applying more narrowly to more institutionalised and often Western-centric practices and beliefs, and do so precisely in order to differentiate such examples of religiosity from non-Western and less institutionalised spiritualities and rituals. 9 Some definitions hinge on the object of worship (God or gods), others on ritual practices, others still on the state of mind which opens itself to it. ${ }^{\text {to }}$ Some insist on religion being a

8 Ward Churchill, Pacifism as Pathology: Reflections on the Role of Armed Struggle in North America (Edinburgh: AK Press, 2007); Andrew Fiala, "Anarchism and Pacifism," in Brill's Companion to Anarchism and Philosophy, ed. Nathan Jun (Leiden: Brill, 20I 8); Uri Gordon, Anarchy Alive!: Anti-Authoritarian Politics from Practice to Theory (London: Pluto, 2008), chap. 4; Vernon Richards, ed. Violence and Anarchism: A Polemic (London: Freedom, I993).

9 Paul Heelas and Linda Woodhead, The Spiritual Revolution: Why Religion Is Giving Way to Spirituality (Oxford: Blackwell, 2005); Philip Sheldrake, Spirituality: A Brief History (Oxford: John Wiley and Sons, 2013).

to John Bowker, "Religion," in The Concise Oxford Dictionary of World Religions ed. John Bowker (Oxford: Oxford University Press, 2000), pp. xviii-xiv; John Hinnells, ed. The Penguin Dictionary of Religions, and ed. (London: Penguin, I995), pp. 4I4-I6; Moojan Momen, The Phenomenon of Religion: A Thematic Approach (Oxford: Oneworld, I999), pp. 26-28, and chap. 3 . 
private matter, sometimes with an explicit determination to keep it independent from politics. ${ }^{\text {I }}$ Others argue that religion cannot but inevitably be political, and that its confinement to the 'private' sphere is actually the result of a political project. ${ }^{\mathrm{I} 2}$ Then there is the category of 'civil religion' to describe politics that looks like 'religion'. ${ }^{\text {'3 }}$

Unsurprisingly, therefore, it is generally expected that a work exploring either religion or anarchist politics will, at the outset, offer a definition that attempts to stake out the parameters of these terms. The fact that our project grapples with not just one disputed term, but two, makes this question of definition all the more important. The introduction to the first volume of Essays in Anarchism and Religion explained how this project emerged,

I Jean Baubérot and Micheline Milo, Laïcités Sans Frontières (Paris: Seuil, 20I I); Ahmet T. Kuru, Secularism and State Policies toward Religion: The United States, France, and Turkey (Cambridge: Cambridge University Press, 2009); Erica Michelle Lagalisse, “"Marginalizing Magdalena”: Intersections of Gender and the Secular in Anarchoindigenist Solidarity Activism," Signs: Journal of Women in Culture and Society 36, no. 3 (20II); Tariq Modood, "Moderate Secularism, Religion as Identity, and Respect for Religion," The Political Quarterly 8I, no. I (2010); Graeme Smith, A Short History of Secularism (London: I.B.Tauris, 2008).

I2 Steve Bruce, Politics and Religion (Cambridge: Polity, 2003); José Casanova, Public Religions in the Modern World (Chicago: University of Chicago Press, I994); William T. Cavanaugh, "A Fire Strong Enough to Consume the House: The Wars of Religion and the Rise of the State," Modern Theology I I, no. 4 (I995); Alexandre Christoyannopoulos and Anthony T. Fiscella, "'Religious' Radicalism," in Routledge Handbook of Radical Politics, ed. Uri Gordon and Ruth Kinna, Stockholm Studies in Comparative Religion (London: Routledge, 20I8); Jonathan Fox, An Introduction to Religion and Politics: Theory and Practice (Oxon: Routledge, 2013); Jeffrey Haynes, ed. Routledge Handbook of Religion and Politics (London: Routledge, 2009); Nikki R. Keddie, "Secularism and Its Discontents," Dodalus I32, no. 3 (2003); Steven Kettell, "Do We Need a 'Political Science of Religion'?," Political Studies Review I 4, no. 2 (20I6); Pippa Norris and Ronald Inglehart, Sacred and Secular: Religion and Politics Worldwide (Cambridge: Cambridge University Press, 20I I).

${ }^{13}$ Robert N. Bellah and Phillip E. Hammond, Varieties of Civil Religion (Eugene, OR: Wipf and Stock, I980); John A. Coleman, "Civil Religion," Sociology of Religion 3 I, no. 2 ( I 970); Emilio Gentile, Politics as Religion, trans. George Staunton (Princeton: Princeton University Press, 200I); John Markoff and Daniel Regan, "The Rise and Fall of Civil Religion: Comparative Perspectives," Sociological Analysis 42, no. 4 (I98I). 
located it in the broader contexts of both the 'resurgence' of religion in politics and the increasing interest in anarchist studies, acknowledged our positionality and the disproportionate focus on Christianity, and summarised a tentative mapping of the territory according to four main categories of enquiry. ${ }^{14}$ It nevertheless left out discussions of definitions. What follows here therefore is an exploration of some of the difficulties inherent in trying to define 'anarchism' and 'religion', and an explanation of why we chose to adopt a flexible approach for this project, followed by a short introduction to each of the chapters in this volume.

\section{'Anarchism'}

It is conventional to begin discussing the definition of anarchism by pointing to the etymology of the term. The suffix -archy is said to refer to the state or the ruler, the prefix an- to a rejection or negation, hence an-archy signals a rejection of the state or ruler. This, however, is somewhat too simplistic, as has been noted and discussed by a number of scholars in anarchist studies. ${ }^{15}$ For one, even the Greek suffix refers to more than just 'the state' (or 'ruler'). It is akin to the Latin prefix pri-, as in: princes and principalities, but also principles, primordial and priority. 'Anarchy', even etymologically, thus hints at more than just a rejection or negation of the modern version of princes and principalities.

${ }^{{ } 4}$ The four areas were: anarchist critiques of religion; anarchist exegesis; anarchist theology, and religious anarchist historiographies. Alexandre Christoyannopoulos and Matthew S. Adams, "Anarchism and Religion: Mapping an Increasingly Fruitful Landscape," in Essays in Anarchism and Religion: Volume I, ed. Alexandre Christoyannopoulos and Matthew S. Adams, Stockholm Studies in Comparative Religion (Stockholm: Stockholm University Press, 20I7). The more detailed exploration of those four main types of enquiries has now been published as Christoyannopoulos and Apps, "Anarchism and Religion."

is Alexandre Christoyannopoulos, Christian Anarchism: A Political Commentary on the Gospel (Exeter: Imprint Academic, 2010), 26970; Francis Dupuis-Déri, "Anarchy in Political Philosophy," in New Perspectives on Anarchism, ed. Nathan Jun and Shane Wahl (Lanham, MD: Lexington, 20I0); Mitchell Verter, "The Anarchism of the Other Person," ibid. 
Furthermore, even though definitions of 'anarchism' notoriously defy consensus, most anarchists today would subscribe to an attempt to interpret the term as indicating a critical and antiauthoritarian position with respect to all forms of hierarchy and domination. This includes top-down political structures such as 'the state', but also neoliberal capitalism (hence the allergic reaction to 'anarcho-capitalism'), patriarchy and heteronormativity, 'religion' (certainly hierarchical religious beliefs and institutions), racism, ableism, speciesism, and so on. To reduce 'anarchism' to 'opposition to the state' therefore overlooks this set of richer challenges to the multifarious expressions of power and discrimination. The state often underwrites and polices these structures of oppression, and there is much about it that earns it dedicated criticism from anarchists, but it is not the only object of their critique, sometimes not even the primary one.

Attempting to define anarchism by turning to concepts such as 'the state' and 'capitalism' also implies an historical gaze that, for some, unduly circumvents a much deeper tradition that opposes manifold forms of authority. For the more historically-minded commentator, to view anarchist politics emerging as a response to the centralising tendencies of the modern nation-state necessarily dates its genesis to, at the earliest, the closing decades of the seventeenth century. Similarly, if we emphasise the importance of capitalism, and locate anarchism's foundation in responses to the depredations of industrialism and the rise of the workers' movement, this timeline is further abridged. If it is meaningless to talk of 'anarchism' before the rise of the modern state or capitalism, where does this leave those that want to see the Levellers or Lao Tzu as essentially anarchist?

There is also the question of method and place, that is, of how and where this criticism is articulated. Some channel their anarchist critique primarily in workplace syndicalism. Some prioritise direct action and street protests, some informed by a determination to remain non-violent, although some dismiss such determination in activism as an expression of dilettantism. Some focus on the written articulation of their ideas, from zines to blogs to philosophical tracts. Some join armed struggles such as in Republican Spain in 1936, or in post-201 I Rojava. Some focus on prefiguring 
political alternatives here and now. Many fuse these different priorities in novel combinations of thought and praxis.

There are, in short, many varieties of anarchism. In our project, since the interaction of 'religion' and 'anarchism' is both understudied and potentially pregnant with a rich variety of fruitful angles of analysis, we have opted to be as open as possible to different declinations of 'anarchism'. In their separate ways, therefore, each author in these volumes of Essays in Anarchism and Religion is implicated in this unforgiving task of definition. As editors, we remain open to the idea that anarchism remains a contested category - the site of manifold, competing definitions - and have encouraged authors to reflect on this vexed issue.

\section{'Religion'}

It is no less difficult to settle on a definition of 'religion', for a different variety of reasons. As Momen argues, although most people think they know what they mean by 'religion', “in-built cultural biases predispose us to view religion in particular ways": Westerners for instance see religion primarily as a system of beliefs; Hindus might lay more emphasis on the performance of ritual activities; and Muslims tend to focus on how one's personal and social life is to be lived. ${ }^{16}$ Moreover, the idea of religion as a 'personal choice' is relatively recent: hitherto your religion was usually that of the family and community in which you were born. ${ }^{17}$ The very categorising of 'religion' as a distinct part of one's compartmentalised life (separate from work, family, hobbies, etc.) is also a product of relatively recent and Western contexts. ${ }^{18}$

It is perhaps not surprising if different scholars embedded in different academic disciplines therefore propose significantly

${ }^{16}$ Momen, The Phenomenon of Religion, pp. 2I-25 (the quote is from p. 2I).

${ }^{7}$ Ibid., pp. 24-25. See also Jeremy Carrette and Richard King, Selling Spirituality: The Silent Takeover of Religion (Abingdon: Routledge, 2005).

${ }^{18}$ Christoyannopoulos and Fiscella, “'Religious' Radicalism.”; Momen, The Phenomenon of Religion, p. 25. 
different definitions of religion. ${ }^{19}$ Some prioritise the metaphysical content, others the sociological characteristics, yet others the psychoanalytical impulse, others still the political function. Some might eschew definitions and point to a variety of characteristics to be found in all 'religion': practical and ritual (the religious performances and celebrations that punctuate days, months and years); experiential and emotional (Paul's or Buddha's conversions, religious music and art, etc.); narrative or mythic (the story of our origins); doctrinal and philosophical (theology, dogma, metaphysics, etc.); ethical and legal (how we are to live our lives); social and institutional (the community of adherents and its social function); and material (the physical buildings and sacred places). ${ }^{20}$ Others will define it more informally as an activity one is "extremely enthusiastic about and does regularly." ${ }^{21}$ Any one of these definitional preferences will result in the inclusion or exclusion of particular examples, the inclusion or exclusion of which might be disputed by others (Buddhism? Confucianism? Football? Shopping?). Several definitions may even result in having to label certain political ideologies as 'religion' (State communism? Nationalism?). ${ }^{22}$

A further difficulty is that what most Westerners instinctively understand as 'religion' is a product of Western history, laden, inevitably, with Westphalian and imperialistic baggage. There are therefore important reasons, from a post-colonial and postWestphalian perspective, to proceed with caution before imposing any exogenous definitions upon a phenomenon some variant of which has consistently been part and parcel of the life and

19 Bowker, "Religion," pp. xviii-xiv; George Chryssides and Ron Geaves, The Study of Religion: An Introduction to Key Ideas and Methods, Second ed. (London: Bloomsbury, 20I4); Peter Connolly, ed. Approaches to the Study of Religion (London: Continuum, I999); Hinnells, The Penguin Dictionary of Religions, pp. 4I4-I6; Momen, The Phenomenon of Religion, pp. 26-28, and chap. 3; Robert A. Segal, ed. The Blackwell Companion to the Study of Religion (Oxford: Blackwell, 2009).

${ }^{20}$ Ninan Smart, The World's Religions, Second ed. (Cambridge: Cambridge University Press, I998), pp. I 2-22.

${ }_{21}$ “Religion," Cambridge University Press, https://dictionary.cambridge. org/dictionary/english/religion.

22 The World's Religions, pp. 22-26. 
thought of every human community for millennia prior to the European Enlightenment. This is not to say that the word 'religion' is polluted beyond repair by statist and colonial Western history, but that the particular context from which the widespread signification of the term as labelling a particular category of things emerged, and the implicit framing that this can still impose, should not be ignored. ${ }^{23}$

With such considerations in mind, our approach has been not to impose contestable limits but to stay open to different definitional approaches. Where the use of a term by an author in these volumes might be controversial, as with 'anarchism', we encouraged some acknowledgement and discussion of those choices. Just as with 'anarchism', though, we have not sought to police the boundaries of the term or proscribe its use in particular contexts a priori.

In editing and presenting essays on 'anarchism' and 'religion', therefore, we adopted an open and flexible approach to both terms' definitions. Our primary interest is not in excluding potential angles of analysis because they did not fit a particular kind of definition, but in creating a space for rigorous scholarly discussion at the overlap of the two, whatever the particular definitional preference of the author. In that sense, perhaps, we have abided by one precept commonly recognised in anarchist approaches to consensus-building.

\section{The essays in this volume}

The first volume contained eight chapters which adopted different combinations of modes of enquiry: Pauli and Blanes were primarily historical interventions; Galvan-Alvarez blended history and exegesis; Podmore engaged in anarchist theology; Meggitt was rooted in Bible studies; Strandberg approached anarchist critiques of religion from a philosophical angle; and Hoppen considered

${ }_{23}$ Christoyannopoulos and Fiscella, “Religious' Radicalism.”; Timothy Fitzgerald, The Ideology of Religious Studies (Oxford: Oxford University Press, 2000); Luca Mavelli and Fabio Petito, eds., Towards a Postsecular International Politics: New Forms of Community, Identity, and Power (London: Palgrave Macmillan, 20I4). 
the mystical anarchism of two particular thinkers. ${ }^{24}$ This volume presents a similarly diverse blend of essays considering anarchism and religion using a variety of modes of enquiry.

The first chapter in this volume, by Lillian Türk and Jesse Cohn, explores some of the tensions between anarchism and religion as debated in New York's famous Jewish-anarchist newspaper Fraye Arbeter Shtime in the period I937-I945. It argues that what united those who defended religion and those who opposed it in the debates hosted by the newspaper is a critique of 'domination', whether religious or not. This chapter also articulates a contribution which for once does not come from the Christian tradition, even though the arguments that are covered apply not only to Jewish perspectives.

Just as recent work on the concept of domination in political theory has emphasised the distinctive things anarchist theorists have to offer to the discussion, the question of ethics has also been recognised as an area where anarchist critiques are especially powerful. In the second chapter, Emma Brown Dewhurst approaches this idea from a novel perspective, suggesting that ethical considerations derived from Christian Byzantine thought are best enacted by adopting practical ideas and critical thinking from communal anarchist thought. Focusing on Maximus the Confessor and Peter Kropotkin, she argues that despite their very different metaphysical starting points, they have similar thoughts on how human beings should act with respect to each other and

${ }^{24}$ Enrique Galván-Álvarez, "Why Anarchists Like Zen? A Libertarian Reading of Shinran (II73-I 263)," in Essays in Anarchism and Religion: Volume I, ed. Alexandre Christoyannopoulos and Matthew S. Adams, Stockholm Studies in Comparative Religion (Stockholm: Stockholm University Press, 2017); Franziska Hoppen, "A Reflection on Mystical Anarchism in the Works of Gustav Landauer and Eric Voegelin,” ibid.; Ruy Llera Blanes, "Mutuality, Resistance and Egalitarianism in a Late Colonial Bakongo Christian Movement," ibid.; Justin Meggitt, "Was the Historical Jesus an Anarchist? Anachronism, Anarchism and the Historical Jesus,” ibid.; Benjamin J. Pauli, “The Catholic Worker, Dorothy Day, and Exemplary Anarchism,” ibid.; Simon D. Podmore, “The Anarchē of Spirit: Proudhon's Anti-Theism \& Kierkegaard's Self in Apophatic Perspective,” ibid.; Hugo Strandberg, "Does Religious Belief Necessarily Mean Servitude? On Max Stirner and the Hardened Heart," ibid. 
to the rest of the world, and that Kropotkin's ideas are therefore particularly useful to Christian ethicists.

The notion that anarchism, and indeed socialist thinking more generally, may have more in common with Christian ethical ideas than their frequently atheistic theorists would be willing to admit, is an established theme in the history of political thought. Anarchists, especially when contemplating not just their thoughts but their deeds, are often perceived in terms of their militant opposition to organised religion, and actions perpetrated under the so-called 'Red Terror' in revolutionary Spain might seem to capture this hostility in sanguinary terms. In his contribution, Pedro Garcia-Guirao adds depth and colour to this image, using film as a tool to probe issues of representation and historical accuracy. Providing a 'panoramic overview' of the portrayal of religion (specifically: Catholicism) in Spanish film productions that could be qualified as 'anarchist', he focuses particularly on films that interrogate the legacies of the Spanish Civil War. It considers both critical portrayals of stereotypical Christianity, and portrayals of Christianity which are more in tune with anarchist preferences.

What is certainly apparent is that rejections by anarchists of religious ideas frequently rest on a questionable understanding of the actual content of these ideas. Justin Bronson Barringer's chapter highlights some of the complexity inherent in, in this instance, Christian thinking, and demonstrates the way in which particular reading strategies can disrupt stereotypical interpretations of complex bodies of thought. He offers an anarchist reading of First Peter, arguing that Peter proposes an unacknowledged and politically radical vision of non-coercion, voluntary association and equality. Barringer also argues that this reading offers a situation whereby oppressive power structures are subverted and the oppressed are freed when those with little power paradoxically subordinate themselves to the existing powers that be.

The role of violence in occasioning social change has been a point of fierce contention throughout anarchism's history. These debates also sometimes have a fundamentally religious inflection, where anarchist activists inspired by Tolstoyan pacifism or Gandhian satyagraha both challenge the efficacy of political violence and ponder the extent to which bloodletting undermines 
anarchism's cardinal insistence on the necessary equation between 'means' and 'ends'. In the fifth chapter, Christos Iliopoulos draws on Friedrich Nietzsche and Walter Benjamin in order to challenge the thesis that Christian anarchist activism must remain dogmatically pacifistic. By promoting a Christianity that, instead of self-negation, adopts an affirmative life stance, and by distinguishing between mythical and divine violence, Iliopoulos argues that Christian anarchists need not remain shackled by passive and resentful readings of Christianity.

By contrast, in the chapter that follows, Sam Underwood argues that Christian anarchists make a compelling and convincing case that nonviolence is the most consistent position with the philosophy of anarchism in general, and should not be a characteristic unique to a specifically Christian anarchism. That is, he contends that the criticisms of violence articulated by Christian anarchists might speak to non-Christian anarchists too, and that nonviolence is actually a central element of anarchist prefiguration.

If Iliopoulos's chapter hints at the breadth of thinkers that are seen as offering something to the historic anarchist tradition in this case Nietzsche, whose poetic assassination of modern ethical pieties inspired anarchists as diverse as Emma Goldman and Herbert Read - this theme is on display once more in Duane Williams' chapter. Rather than Nietzsche, Williams focuses on another thinker whose coruscating prose and dogged unconventionality has seen him positioned within the anarchist orbit: William Blake. Williams examines the extent to which Blake's writings on law and religion make him an anarchist, and demonstrates how Blake's anarchistic and religious tendencies are fused in a novel intellectual edifice. He does this by exploring Blake's opposition to both judicial and moral law, analysing his complete mistrust of institutional state religion, and examining Blake's reading of Jesus as a bold and inspirational transgressor of that law.

In the final chapter, Erica Lagalisse offers a deep history of the interlacing of anarchist and religious ideas and practices. Lagalisse investigates the religious and theological roots tied to the secret societies of the radical Enlightenment from which modern anarchism emerged as a distinctive politics. In the process she explores the hidden correspondences between classical anarchism, 
Renaissance magic and occult philosophy, and questions the widespread attachment to the 'secular' on the Left, as well as its gendered and colonial inflections.

Lagalisse's interrogation of the gendered and colonial implications of conventional leftist secularism points also to the modest steps taken in this collection to deal with the enduring Eurocentrism and androcentrism that so often beset academic research. We welcome the fact that this volume has both more female scholars, and more reflections on non-Christian religious contexts, than the last, but equally acknowledge that there is a long way to go and that it is important to continue to broaden the scope of this project. Indeed, given the fluidity that this introduction, and the chapters comprising this volume, have all highlighted as a defining characteristic of the anarchist tradition, it is important that scholarship on this tradition should seek to address these problems. Nevertheless, while we are committed to these philosophical and methodological principles, a project of this nature will always come face-to-face with practicalities and structural biases that hinder the inclusiveness we aspire to achieve. The contributors remain overwhelmingly male, their contributions are often rooted in literatures defined by their Eurocentrism, and Christianity remains a hegemonic lens. We are determined, however, to address this issue. This is the second volume of a three-part series comprised of papers all emanating from the Anarchist Studies Conference held at Loughborough University in 2012 , but we plan a fourth volume in this project that addresses these issues of positionality, intersectionality, and inclusivity directly. In contrast to the looser organisation of the first three volumes, the fourth will examine these dynamics head on, but also interrogate the conventions that these initial volumes are helping to cultivate concerning our object of study. The fourth volume, therefore, will be concerned as much with the legacy that our scholarship is creating, as with the intricate relationship between anarchism and religion.

But these self-flagellating mea culpas do not detract from the power and importance of this collection. Just as with Volume I, we continue to be astonished by the interdisciplinary breadth of this scholarship, by its thought-provoking originality, and by 
the enthusiastic and authentic commitment by its authors to explore these areas. Editing these papers has been stimulating and enriching, and we hope that encountering them will prove just as rewarding to new readers, testing in the process some prevalent assumptions about how 'anarchism' and 'religion' should be defined.

Alexandre Christoyannopoulos and Matthew S. Adams, May 2018

\section{References}

Adams, Matthew S. "The Possibilities of Anarchist History: Rethinking the Canon and Writing History." Anarchist Developments in Cultural Studies I (2013): 33-63.

Barclay, Harold. “Anarchist Confrontations with Religion.” In New Perspectives on Anarchism, edited by Nathan Jun and Shane Wahl, I69-8 5. Lanham, MD: Lexington, 2010.

Baubérot, Jean, and Micheline Milo. Laïcités Sans Frontières. Paris: Seuil, 2OI I.

Bellah, Robert N., and Phillip E. Hammond. Varieties of Civil Religion. Eugene, OR: Wipf and Stock, I980.

Bowker, John. "Religion." In The Concise Oxford Dictionary of World Religions edited by John Bowker. Oxford: Oxford University Press, 2000.

Bruce, Steve. Politics and Religion. Cambridge: Polity, 2003.

Carrette, Jeremy and Richard King. Selling Spirituality: The Silent Takeover of Religion. Abingdon: Routledge, 2005.

Casanova, José. Public Religions in the Modern World. Chicago: University of Chicago Press, I994.

Cavanaugh, William T. "A Fire Strong Enough to Consume the House: The Wars of Religion and the Rise of the State." Modern Theology I I, no. 4 (October I995): 397-420.

Christoyannopoulos, Alexandre. Christian Anarchism: A Political Commentary on the Gospel. Exeter: Imprint Academic, 20 Iо. 
- "Christian Anarchism: A Revolutionary Reading of the Bible." In New Perspectives on Anarchism, edited by Nathan Jun and Shane Wahl, I49-67. Lanham, MD: Lexington, 2010.

Christoyannopoulos, Alexandre, and Matthew S. Adams. "Anarchism and Religion: Mapping an Increasingly Fruitful Landscape." In Essays in Anarchism and Religion: Volume I, edited by Alexandre Christoyannopoulos and Matthew S. Adams. Stockholm Studies in Comparative Religion, I-I 7. Stockholm: Stockholm University Press, 2017.

Christoyannopoulos, Alexandre, and Lara Apps. "Anarchism and Religion." In Brill's Companion to Anarchism and Philosophy, edited by Nathan Jun, I 20-5 I. Leiden: Brill, 20 I 8.

Christoyannopoulos, Alexandre, and Anthony T. Fiscella. “'Religious' Radicalism." In Routledge Handbook of Radical Politics, edited by Uri Gordon and Ruth Kinna. Stockholm Studies in Comparative Religion, I-I7. London: Routledge, 20 I 8.

Chryssides, George, and Ron Geaves. The Study of Religion: An Introduction to Key Ideas and Methods. Second ed. London: Bloomsbury, 20I4.

Churchill, Ward. Pacifism as Pathology: Reflections on the Role of Armed Struggle in North America. Edinburgh: AK Press, 2007.

Coleman, John A. “Civil Religion.” Sociology of Religion 3 I, no. 2 (July I970): 67-77.

Connolly, Peter, ed. Approaches to the Study of Religion. London: Continuum, I999.

Dupuis-Déri, Francis. "Anarchy in Political Philosophy." In New Perspectives on Anarchism, edited by Nathan Jun and Shane Wahl, 9-23. Lanham, MD: Lexington, 2010.

Faure, Sébastien. "Does God Exist? Twelve Proofs of the NonExistence of God." The Anarchist Library, http://theanarchistlibrary. org/library/sebastien-faure-does-god-exist.

Fiala, Andrew. "Anarchism and Pacifism." In Brill's Companion to Anarchism and Philosophy, edited by Nathan Jun, I 53-70. Leiden: Brill, 20 I 8. 
Fitzgerald, Timothy. The Ideology of Religious Studies. Oxford: Oxford University Press, 2000.

Fox, Jonathan. An Introduction to Religion and Politics: Theory and Practice. Oxon: Routledge, 2013.

Gallie, W. B. "Essentially Contested Concepts." In The Importance of Language, edited by M. Black, I2I-46. Ithaca, NY: Cornell University Press, 1962.

Galván-Álvarez, Enrique. "Why Anarchists Like Zen? A Libertarian Reading of Shinran (II73-I263)." In Essays in Anarchism and Religion: Volume I, edited by Alexandre Christoyannopoulos and Matthew S. Adams. Stockholm Studies in Comparative Religion, 78-123. Stockholm: Stockholm University Press, 2017.

Gentile, Emilio. Politics as Religion. Translated by George Staunton. Princeton: Princeton University Press, 200I.

Gordon, Uri. Anarchy Alive!: Anti-Authoritarian Politics from Practice to Theory. London: Pluto, 2008.

Graham, Robert. "Black Flame: A Commentary." Anarchist Developments in Cultural Studies I (2013): I89-92.

Haynes, Jeffrey, ed. Routledge Handbook of Religion and Politics. London: Routledge, 2009.

Heelas, Paul, and Linda Woodhead. The Spiritual Revolution: Why Religion Is Giving Way to Spirituality. Oxford: Blackwell, 2005.

Hinnells, John, ed. The Penguin Dictionary of Religions. 2nd ed. London: Penguin, I995.

Hoppen, Franziska. “A Reflection on Mystical Anarchism in the Works of Gustav Landauer and Eric Voegelin." In Essays in Anarchism and Religion: Volume I, edited by Alexandre Christoyannopoulos and Matthew S. Adams. Stockholm Studies in Comparative Religion, I98-237. Stockholm: Stockholm University Press, 20 I7.

Jun, Nathan. "Anarchism and Philosophy: A Critical Introduction." In Brill's Companion to Anarchism and Philosophy, edited by Nathan Jun, I-38. Leiden: Brill, 2018.

—. "Rethinking the Anarchist Canon: History, Philosophy, and Interpretation." Anarchist Developments in Cultural Studies I (2OI3): 82-II6. 
Keddie, Nikki R. “Secularism and Its Discontents.” Doedalus I 32, no. 3 (2003): I4-30.

Kettell, Steven. "Do We Need a 'Political Science of Religion'?”. Political Studies Review I4, no. 2 (2016): 2 IO-22.

Kinna, Ruth, and Süreyyya Evren. "Introduction: Blasting the Canon." Anarchist Developments in Cultural Studies I (20I3): I-6.

Kuru, Ahmet T. Secularism and State Policies toward Religion: The United States, France, and Turkey. Cambridge: Cambridge University Press, 2009.

Lagalisse, Erica Michelle. “"Marginalizing Magdalena”: Intersections of Gender and the Secular in Anarchoindigenist Solidarity Activism." Signs: Journal of Women in Culture and Society 36, no. 3 (Spring 2OII): 653-78.

Llera Blanes, Ruy. "Mutuality, Resistance and Egalitarianism in a Late Colonial Bakongo Christian Movement.” In Essays in Anarchism and Religion: Volume I, edited by Alexandre Christoyannopoulos and Matthew S. Adams. Stockholm Studies in Comparative Religion, 5 I-77. Stockholm: Stockholm University Press, 2017.

Markoff, John, and Daniel Regan. "The Rise and Fall of Civil Religion: Comparative Perspectives.” Sociological Analysis 42, no. 4 (I98I): $333-52$.

Mavelli,Luca, and Fabio Petito, eds. Towards a Postsecular International Politics: New Forms of Community, Identity, and Power. London: Palgrave Macmillan, 20I4.

Meggitt, Justin. "Was the Historical Jesus an Anarchist? Anachronism, Anarchism and the Historical Jesus." In Essays in Anarchism and Religion: Volume I, edited by Alexandre Christoyannopoulos and Matthew S. Adams. Stockholm Studies in Comparative Religion, I24-97. Stockholm: Stockholm University Press, 2017.

Modood, Tariq. "Moderate Secularism, Religion as Identity, and Respect for Religion.” The Political Quarterly 8I, no. I (2010): 4-I4.

Momen, Moojan. The Phenomenon of Religion: A Thematic Approach. Oxford: Oneworld, I999.

Most, Johann. “The God Pestilence.” Anarchy Archives, http://dward mac.pitzer.edu/Anarchist_Archives/bright/most/godpest.html. 
Norris, Pippa, and Ronald Inglehart. Sacred and Secular: Religion and Politics Worldwide. Cambridge: Cambridge University Press, 20 I I.

Pauli, Benjamin J. "The Catholic Worker, Dorothy Day, and Exemplary Anarchism." In Essays in Anarchism and Religion: Volume I, edited by Alexandre Christoyannopoulos and Matthew S. Adams. Stockholm Studies in Comparative Religion, I 8-50. Stockholm: Stockholm University Press, 2017.

Podmore, Simon D. “The Anarchē of Spirit: Proudhon's Anti-Theism \& Kierkegaard's Self in Apophatic Perspective." In Essays in Anarchism and Religion: Volume I, edited by Alexandre Christoyannopoulos and Matthew S. Adams. Stockholm Studies in Comparative Religion, 238-82. Stockholm: Stockholm University Press, 2017.

“Religion.” Cambridge University Press, https://dictionary.cambridge. org/dictionary/english/religion.

Richards, Vernon, ed. Violence and Anarchism: A Polemic. London: Freedom, I993.

Schmidt, Michael, and Lucien van der Walt. Black Flame: The Revolutionary Class Politics of Anarchism and Syndicalism. Oakland: AK, 2009.

Segal, Robert A., ed. The Blackwell Companion to the Study of Religion. Oxford: Blackwell, 2009.

Sheldrake, Philip. Spirituality: A Brief History. Oxford: John Wiley and Sons, 20I3.

Smart, Ninan. The World's Religions. Second ed. Cambridge: Cambridge University Press, I998.

Smith, Graeme. A Short History of Secularism. London: I.B.Tauris, 2008.

Strandberg, Hugo. "Does Religious Belief Necessarily Mean Servitude? On Max Stirner and the Hardened Heart." In Essays in Anarchism and Religion: Volume I, edited by Alexandre Christoyannopoulos and Matthew S. Adams. Stockholm Studies in Comparative Religion, 283-307. Stockholm: Stockholm University Press, 2017.

The Anarchist FAQ Editorial Collective. “An Anarchist Faq.” https:// theanarchistlibrary.org/library/the-anarchist-faq-editorial-collectivean-anarchist-faq\#toc7. 
van der Walt, Lucien. “(Re)Constructing a Global Anarchist and Syndicalist Canon: A Response to Robert Graham and Nathan Jun on Black Flame." Anarchist Developments in Cultural Studies I (20I3): I93-203.

Verter, Mitchell. "The Anarchism of the Other Person." In New Perspectives on Anarchism, edited by Nathan Jun and Shane Wahl, 67-83. Lanham, MD: Lexington, 2010.

Walter, Nicolas. "Anarchism and Religion.” The Raven: anarchist quarterly 25 7, no. I (Spring I994): 3-9.

Woodcock, George. Anarchism: A History of Libertarian Ideas and Movements. London: Penguin, I986. 